\title{
Pengaruh Model Inquiry-Based Learning dan Motivasi Belajar Terhadap Keterampilan Berpikir Kritis Siswa Kelas V SD
}

\author{
Udan Miharja ${ }^{1 *}$, Maman Rumanta 2, Ucu Rahayu ${ }^{3}$ \\ 1 Universitas Terbuka, Serang, Indonesia \\ 2 Universitas Terbuka, Serang, Indonesia \\ 3 Universitas Terbuka, Serang, Indonesia \\ *Corresponding author: udanmiharja@gmail.com
}

\begin{abstract}
The ability to think critically plays an important role in preparing students to be good problem solvers and to be able to make decisions and conclusions that can be accounted for academically. The low critical thinking skills of students in science subjects became the background for this research. The purpose of this study was to determine the effect of the inquiry based learning model and learning motivation on students' critical thinking skills. The research method used in this research is a quasi-experimental in which this research uses two sample groups, namely the experimental class and the control class. The selection of the research sample was carried out using random sampling. The research data was conducted using tests to see critical thinking skills and observation sheets to see student learning motivation. The data obtained were analyzed using two-way analysis of variance (Two Way ANOVA) to analyze the influence between the two variables. The results showed the effect of inquiry based learning on students' critical thinking skills as indicated by a significance value of $0.004<0.05$; there are differences in critical thinking skills of students who have low and high motivation, this can be seen from the significance value of $0.000<0.05$; however, there is no interaction effect between the inquiry-based learning model and student learning motivation as seen from the significance value of $0.736>0.05$.
\end{abstract}

Keywords: critical thinking; inquiry based learning; motivation to learn

\section{ABSTRAK}

Kemampuan berpikir kritis berperan penting dalam mempersiapkan siswa menjadi pemecah masalah yang baik serta mampu membuat keputusan maupun kesimpulan yang dapat dipertanggung jawabkan secara akademis. Rendahnya keterampilan berpikir kritis siswa pada mata pelajaran IPA menjadi latar belakang dilakukannya penelitian ini. Tujuan dari penelitian ini adalah untuk mengetahui pengaruh model inquiry based learning dan motivasi belajar terhadap keterampilan berpikir kritis siswa. Metode penelitian yang digunakan dalam penelitian ini adalah quasi eksperimen yang mana penelitian ini menggunakan dua kelompok sampel yaitu kelas eksperimen dan kelas kontrol. Pemilihan sampel penelitian dilakukan dengan menggunakan random sampling. Data penelitian dilakukan dengan menggunakan tes untuk melihat keterampilan berpikir kritis dan angket untuk melihat motivasi belajar siswa. Data yang didapat dianalisis dengan menggunakan analisis varians dua jalur (Two Way ANOVA) untuk menganalisis pengaruh antara dua variabel. Hasil penelitian menunjukkan adanya pengaruh inquiry based learning terhadap keterampilan berpikir kritis siswa yang ditunjukkan dengan nilai signifikansi sebesar 0,004 < 0,05; terdapat perbedaan keterampilan berpikir kritis siswa yang memiliki motivasi rendah dan tinggi, hal ini terlihat dari nilai signifikansi sebesar $0,000<0,05$; akan tetapi tidak terdapat pengaruh interaksi antara model inquiry based learning dengan motivasi belajar siswa yang terlihat dari nilai signifikansi sebesar 0,736 $>0,05$.

Kata Kunci: berpikir kritis; inquiry based learning; motivasi belajar

\section{Pendahuluan}

Pendidikan di era globalisasi memiliki peran penting bagi peradaban kehidupan manusia. Pendidikan berperan untuk membentuk generasi emas Indonesia sehingga tumbuh dan berkembang secara aktif dan dinamis menjadi manusia yang edukatif, berkualitas, memiliki multi intelektual, kompetitif, dan produktif. Adapun upaya untuk mewujudkan harapan 
tersebut dibutuhkan manusia yang tidak hanya cerdas berpikir dari kegiatan menghafal konsep, melainkan kecerdasan berpikir yang dibentuk dari proses pembiasaan untuk memecahkan dan menyelesaikan masalah serta memiliki kemampuan berpikir kritis serta kreatif. Kemampuan berpikir kritis berperan penting dalam mempersiapkan siswa menjadi pemecah masalah yang baik serta mampu membuat keputusan maupun kesimpulan yang dapat dipertanggung jawabkan secara akademis (Ariyana, 2018). Siswa sebagai produk pendidikan dituntut memiliki delapan kompetensi pokok dalam kecakapan pendidikan abad 21 yakni communication skills, critical and creative thinking skills, inquiry/reasoning skills, interpersonal skills, multicultural/multilingual literacy, problem solving, information/digital literacy; and technological skills. Keterampilan berpikir kritis merupakan proses mental seseorang yang terorganisasi dengan sistematis dan baik serta sangat berperan dalam proses mengambil keputusan dalam memecahkan masalah dengan menganalisis dan menginterpretasi data dalam kegiatan penemuan. Dengan demikian, siswa yang berpikir kritis, ketika dihadapkan suatu permasalahan, pemikiran kritisnya akan mendorong untuk cerdas dalam mengambil keputusan serta dapat memecahkan permasalahan tersebut (Susilo, 2012). Sebagai salah satu kompetensi yang dikembangkan dari diri siswa dalam proses pembelajaran, keterampilan berpikir kritis siswa akan bergantung pada kemampuan guru dalam merancang kegiatan pembelajaran. Sbagaimana yang dikemukakan Purnomo, dkk (2020) bahwa peran guru di era 4.0 tidak sekedar dapat mampu menggunakan teknologi saja, namun guru dituntut untuk dapat mengelola kelas dengan baik sehingga membuat suasana kelas menjadi lebih interaktif, menyenangkan, dan juga inovatif yang diintegrasikan dengan teknologi (Purnomo, Mahpudin, \& Sunanto, 2020). Selain itu, sistem pembelajaran akan berhasil manakala siswa memiliki motivasi dalam proses pembelajaran. Demi memperoleh hasil belajar yang baik maka guru dituntut kreatif membangkitkan dan membangun motivasi belajar siswa (Suprihatin, 2015). Merujuk pada pendapat tersebut, guru dalam merancang pembelajaran hendaknya berorientasi kepada tujuan pembelajaran sehingga akan berdampak kepada keberhasilan tujuan pembelajaran serta harus kreatif dalam membangun memotivasi siswa dalam proses pembelajaran. Ilmu Pengetahuan Alam (IPA) sangat erat kaitannya dengan cara mencari tahu tentang fenomena alam, maka IPA bukan hanya dipandang penguasaan sekumpulan pengetahuan yang berupa fakta-fakta, konsep-konsep, atau prinsip-prinsip semata tetapi juga dipandang sebagai suatu proses penemuan sebagai wahana bagi siswa dalam mempelajari dirinya sendiri dalam alam sekitarnya (Ardiyanti \& Winarti, 2013). Karena IPA dipandang sebagai ilmu tentang cara mencari tahu tentang fenomena alam bukan hanya sebatas kumpulan ilmu, fakta, dan prinsip, maka lebih jauh IPA dipandang sebagai wahana bagi siswa dalam mempelajari dirinya sendiri dalam alam sekitarnya. Berdasarkan hasil pengamatan di SDN Serang 03, keterampilan berpikir kritis siswa masih tergolong rendah, hal ini diakibatkan oleh, 1) kurang bervariasinya model pembelajaran yang digunakan oleh guru, 2) rendahnya motivasi belajar siswa yang ditandai dengan rendahnya antusisme siswa ketika guru memberi kesempatan untuk bertanya. Penelitian terdahulu yang dilakukan oleh Wardani dengan judul The Effect of Inquiry Learning Model with Pictorial Riddle Method on Students' Creative Thinking Ability, model inquiry based learning dengan metode teka-teki bergambar berpengaruh secata signifikan terhadap kemampuan berpikir kreatif siswa (Wardani, Gummah, \& Ahzan, 2019). Selain itu, penelitian yang dilakukan Alim dengan judul Implementation of Ethnoscience-based Guided Inquiry Learning on The Scientific Literacy and The Character of Elementary School Students, 
model inkuiri terbimbing memiliki pegaruh signifikan terhadap implementasi pembelajaran berbasis etnoscience dan penguasaannya literasi siswa (Alim, Sarwi, \& Subali, 2019). Berdasarkan latar belakang tersebut penelitian ini dilakukan dengan tujuan, 1) mendeskripsikan pengaruh model pembelajaran inquiry based learning terhadap keterampilan berpikir kritis siswa; 2) mendeskripsikan pengaruh motivasi belajar siswa terhadap keterampilan berpikir kritis siswa; 3) melihat pengaruh interaksi antara model inquiry based learning dengan motivasi belajar siswa.

Putri, Nevrita, \& Hindrasti, (2019) keterampilan berpikir kritis dapat didefinisikan sebagai suatu keterampilan berpikir yang memiiki alasan dan reflektif terhadap apa yang diyakini dan dilakukan. Siswa yang memiliki keterampilan berpikir kritis akan dapat menarik sebuah kesimpulan dengan cerdas, sebagaimana dikemukakan oleh Asmawati, (2015) berpikir kritis dapat memungkinkan siswa untuk menganalisis pikirannya dalam menentukan pilihan dan menarik sebuah kesimpulan dengan cerdas. Ngalimun, (2017) keterampilan berpikir kritis (critical thinking skills) adalah keterampilan berpikir yang dilakukan dengan mengoprasikan potensi intelektual siswa untuk menganalisis sehingga dapat mengambil keputusan secara tepat. Siswa yang memiliki keterampilan berpikir kritis memiliki ciri-ciri sebagai berikut: 1) Cerdas dalam mendeteksi permasalahan, 2) gemar mengumpulkan data sebagai pembuktian faktual, 3) dapat menginterpretasi gambar atau kartun, 4) membuat interpretasi pengetian, definisi, reasoning, dan isu-isu kontoversi, 5) dapat mendaftar segala akibat yang mungkin terjadi atau alternatif pemecahan masalah, ide, dan kondisi tertentu, dan 6) mampu menarik kesimpulan dari data yang ada dan terseleksi (Wihartanti, et.al. 2019). Rahayuni (2016) dalam penelitiannya yang berjudul hubungan keterampilan berpikir kritis dan literasi sains pada pembelajran IPA terpadu dengan model PBM dan STM menyimpulkan bahwa terdapat korelasi kuat antara keterampilan berpikir kritis dan literasi sains, lebih jauh Rahayu mengungkapkan bahwa keterampilan berpikir kritis siswa dapat dilatih dan dikembangkan melalui pelajaran IPA dengan pembelajaran yang berpusat pada siswa.

IPA meruakan mata pelajaran yang berusaha memahami alam semesta melalui cara melakukan penelitian penguji, penyusun teori, serta menggunakan prosedur yang tepat, dan dapat dijelaskan dengan penalaran logis sehingga mendapatkan kesimpulan. Menurut Nurmala, Ansori, \& Saputra (2019) Pembelajaran IPA pada kurikulum 2013 memiliki peranan dalam mengembangkan pengetahuan, sikap, dan keterampilan siswa, IPA juga memiliki perkembangan dari masa kemasa. Kurniawati, (2019) IPA meruakan mata pelajaran yang berusaha memahami alam semesta melalui cara melakukan penelitian penguji, penyusun teori, serta menggunakan prosedur yang tepat, dan dapat dijelaskan dengan penalaran logis sehingga mendapatkan kesimpulan. Pembelajaran IPA dipandang sebagai dimensi produk dan proses, maka pembelajaran yang dilakukan selayaknya mengajarkan bagaimana pengetahuan tersebut ditemukan sendiri oleh siswa itu sendiri. Pembelajaran IPA merupakan pembelajaran yang memberikan pengalaman belajar kepada siswa yang berusaha membahas tentang fenomena alam dan isinya dengan cara melakukan penelitian penguji, penyusun teori, serta menggunakan prosedur yang tepat, dan dapat dijelaskan dengan penalaran logis sehingga mendapatkan kesimpulan yang ditemukan sendiri oleh siswa.

Salah satu model pembelajaran yang memberikan keleluasaan kepada siswa untuk mencari dan menemukan konsep-konsep dalam IPA adalah inquiry based learning (IBL). Budiyanto (2016) mengungkapkan bahwa pembelajaran berdasarkan model IBL adalah 
rangkaian kegiatan pembelajaran yang menekankan pada proses berpikir secara kritis dan analitis dalam mencari dan menemukan sendiri jawaban yang sudah pasti dari suatu masalah yang dipertanyakan sehingga menciptakan kondisi sedemikian rupa agar siswa dapat mengambil peran sebagai ilmuan. Sementara itu Hamalik (2006) mendefinisikan model IBL merupakan model yang pada dasarnya adalah proses mental dimana siswa diupayakan mengasimilasi suatu konsep-konsep dan prinsip-prinsip mislanya mengamati, menggolongkan, membuat dugaan, menjelaskan, mengukur, dan membuat kesimpulan dan sebagainya. Sanjaya (2016) menjelaskan ada tiga karakteristik utaman dalam model IBL yaitu: 1). Model IBL menekankan kepada aktivitas siswa secara maksimal untuk dapat mencari dan menemukan. Artinya model pembelajaran ini memposisikan siswa sebagai subjek belajar. Peran siswa menemukan sendiri ini pelajaran itu bukan secara verbal menerima penjelasan dari guru; 2). Seluruh rangkaian aktivitas yang dilakukan siswa untuk mencari dan menemukan jawaban yang dipertanyakan, sehingga diharapkan menumbuhkan sikap rasa percaya diri (optimis). Aktivitas pembelajaran biasanya dilakukan melalui proses tanya jawab antara guru dengan siswa. Oleh karenanya kemampuan seorang guru dalam menggunakan teknik bertanya menjadi modal atau syarat utama dalam melakukan model pembelajaran inkuiri; 3). Tujuan dari pengimplementasian inkuiri dalam pembelajaran yaitu untuk mengembangkan kemampuan berpikir sistematis, logis, dan berpikir kritis atau menumbuhkan kemampuan intelektual sebagai dari proses mental. Dengan demikian, dalam penerapan model inkuiri siswa tidak hanya dituntut untuk menguasai konsep pelajaran akan tetapi bagaimana mereka dapat menggunakan kemampuan (potensi) yang dimilikinya.

\section{Metode Penelitian}

Metode penelitian yang digunakan dalam penelitian ini adalah quasi experiment pretespostes dengan rancangan desain faktorial $2 \times 2$. Metode penelitian ini dipilih dengan alasan peneliti ingin mengungkap hubungan sebab akibat yang melibatkan kelompok kontrol, oleh karena itu pada pelaksanaan penelitian ini menggunakan dua kelompok kelas yaitu kelas eksperimen dengan diterapkan model IBL terbimbing, sedangkan pada kelas kontrol dengan IBL terbuka. Tiap-tiap kelompok ini akan dibagi ke dalam dua kategori berdasarkan tingkat motivasi belajar siswa yang dimiliki, yaitu siswa yang memiliki motivasi tinggi dan siswa yang memiliki motivasi rendah.

Desain faktorial 2x2 digunakan apabila ada dua atau lebih variabel dengan masingmasing variabel memiliki lebih dari satu situasi. Adapun dalam penelitian ini pengelompokan data dibedakan melalui dua perlakuan yaitu model IBL dan motivasi belajar yang disebut faktor atau main effect dan perbedaan pada tiap treatmen disebut level. Pada penelitian terdapat dua level pada model pembelajaran yaitu (A1) merupakan kelompok belajar dengan menggunakan model IBL dan (A2) merupakan kelompok belajar dengan model konvensional. Faktor motivasi belajar juga terdapat dua level yaitu siswa yang memiliki motivasi belajar tinggi (B1) dan siswa yang memiliki motivasi belajar rendah (B2). Masing-masing varibel terdiri dari dua cara maka desain ini dinamakan 2x2 factorial design. 
Tabel 1. Desain Penelitian

\begin{tabular}{ccc}
\hline \multirow{2}{*}{$\begin{array}{c}\text { Motivasi Belajar } \\
\text { (B) }\end{array}$} & \multicolumn{2}{c}{ Model Pembelajaran (A) } \\
& (A1) & Model IBL Terbuka \\
\hline Tinggi (B1) & A1B1 & A2B1 \\
Rendah (B2) & A1B2 & A2B2 \\
\hline
\end{tabular}

Keterangan:

A1 : Kelompok siswa yang diajar den gan menggunakan model IBL terbımbing

A2 : Kelompok siswa yang diajar dengan menggunakan model IBL terbuka

B1 : Kelompok siswa yang memiliki motivasi belajar tinggi

B2 : Kelompok siswa yang memiliki motivasi belajar rendah

A1B1 : Kelompok siswa yang belajar dengan menggunakan model IBL terbimbing dengan motivasi belajar tinggi

A1B2 : Kelompok siswa yang belajar dengan menggunakan model IBL terbimbing dengan motivasi belajar rendah

A2B1 : Kelompok siswa yang belajar dengan menggunakan model IBL terbuka dengan motivasi belajar tinggi

A2B2 : Kelompok siswa yang belajar dengan menggunakan model IBL terbuka dengan motivasi belajar rendah

Waktu penelitian dilakukan pada tahun ajaran 2020/2021. Adapun pemilihan sampel penelitian dilakukan dengan teknik purposive sampling yang mana pemilihan sampel dilakukan berdasarkan kriteria-kriteria tertentu. Berdasarkan teknik pengambilan sampel tersebut, Subjek dalam penelitian ini adalah kelas V SD Negeri Serang 03 yang mana terdapat dua kelas yaitu kelas VA dan kelas VB. Secara garis besar, penelitian ini ingin mendeskripsikan pengaruh inquiry based learning dan motivasi belajar terhadap keterampilan berpikir kritis siswa pada mata pelajaran IPA.

Instrumen yang digunakan dalam pengumpulan data penelitian adalah, test keterampilan berpikir kritis untuk mengetahui keterampilan berpikir kritis siswa pada mata pelajaran IPA, dan angket motivasi belajar yang digunakan untuk mengetahui tingkat motivasi belajar siswa pada masing-masing kelas, pengelompokkan motivasi belajar siswa dengan cara mengurutkan nilai motivasi belajar siswa dan membagi ke dalam dua kelompok yakni kelompok atas (kelompok dengan motivasi tinggi) dan kelompok bawah (kelompok dengan motivasi rendah). Setelah terkumpul, data dianalisis dengan menggunakan Analsiis Varians dua jalur (Two Way Anova). Analisis varians dua jalur digunakan untuk menganalisis pengaruh antara dua variabel bebas yaitu model IBL dan motivasi belajar terhadap keterampilan berpikir kritis siswa.

\section{Hasil dan Pembahasan}

Analisis dan pengujian hipotesis penelitian dilakukan dengan menggunakan SPSS 20.00 for windows. Dalam hal ini, dilihat sejauh mana perbedaan antara motivasi belajar antara siswa kelas eksperimen (IBL terbimbing) dan kelas kontrol (IBL terbuka). Selain itu, data motivasi belajar siswa dikelompokkan menjadi kelompok atas dan kelompok bawah. Kelompok atas adalah data siswa yang mempunyai motivasi belajar yang kuat, sedangkan kelompok bawah adalah data siswa yang mempunyai motivasi belajar yang lemah. Tujuan 
dari dikelompokkannya data motivasi belajar siswa tersebut adalah agar dapat diketahui apakah terdapat perbedaan keterampilan berpikir kritis antara siswa yang mempunyai motivasi belajar kuat dengan siswa yang mempunyai motivasi belajar lemah.

\section{Pengaruh Inquiry Based Learning Terhadap Keterampilan Berpikir Kritis}

Pada bagian ini peneliti membandingkan keterampilan berpikir kritis siswa pada mata pelajaran IPA antara siswa yang belajar dengan model IBL terbimbing dengan siswa yang belajar dengan model (IBL terbuka). Nilai signifikansi sebesar 0,004 yang mana nilai signifikansi tersebut lebih kecil dari 0,05 yang artinya terbedaan rata-rata kemampuan berpikir kritis siswa antara siswa yang belajar dengan menggunakan IBL terbimbing dengan siswa yang belajar dengan model IBL terbuka. Karena rata-rata skor kemampuan berpikir kritis siswa yang belajar menggunakan pembelajaran inquiri lebih tinggi dibandingkan dengan model IBL terbuka, maka siswa yang belajar menggunakan inquiri memiliki kemampuan berpikir kritis yang lebih baik dibandingkan dengan siswa yang belajar dengan model IBL terbuka.

\section{Pengaruh Motivasi Belajar Terhadap Keterampilan Berpikir Kritis Siswa}

Peneliti membandingkan keterampilan berpikir kritis siswa, yaitu antara siswa yang memiliki motivasi belajar tinggi dengan siswa yang memiliki motivasi belajar rendah. Berdasarkan tabel di atas, nilai signifikansi sebesar 0,000 lebih kecil dari 0,05, maka $H_{0}$ ditolak, sehingga terdapat perbedaan rata-rata kemampuan berpikir kritis antara siswa yang memiliki motivasi tinggi dan rendah. Karena rata-rata skor kemampuan berpikir kritis siswa yang memiliki motivasi tinggi lebih tinggi dibandingkan dengan siswa yang memiliki motivasi rendah, maka siswa yang bermotivasi tinggi memiliki kemampuan berpikir kritis yang lebih baik dibandingkan dengan siswa bermotivasi rendah.

\section{Pengaruh Interaksi Antara Model Inquiry Based Learning Dengan Motivasi Belajar Siswa}

Pada bagian ini, peneliti mencoba melihat terdapat atau tidaknya interaksi antara model inquiry based learning dengan motivasi belajar, berdasarkan tabel di atas, nilai signifikansi sebesar 0,736 lebih tinggi dari 0,05, dengan demikian maka $H_{0}$ diterima yang artinya tidak ada interaksi antara model pembelajaran dan motivasi terhadap kemampuan berpikir kritis. Oleh karena hasil uji hipotesis menunjukkan tidak terdapat interaksi antara model inquiry based learning dengan motivasi belajar dan hasil dari pengujian hipotesis pertama menunjukkan terdapat perbedaan yang signifikan ketererampilan berpikir kritis siswa antara yang menggunakan model IBL terbimbing dengan yang menggunakan model IBL terbuka, maka dapat dipastikan bahwa skor kterampilan berpikir kritis selalu lebih tinggi yang menggunaakn pembelajaran inquiri untuk semua jenjang motivasi.

Setelah dilakukan penelitian terhadap kelas eksperimen dan kelas kontrol, tampak bahwa nilai rata-rata keterampilan berpikir kritis siswa pada kelas eksperiman yakni siswa yang mendapat pembelajaran dengan menggunakan IBL terbimbing lebih besar jika dibandingkan dengan siswa kelas kontrol yakni siswa yang tidak diberi pembelajaran dengan menggunakan IBL terbuka. Nilai rata-rata keterampilan berpikir kritis siswa kelas eksperimen yaitu sbesar 74 dari nilai maksimum 100 sedangkan nilai rata-rata keterampilan berpikir kritis siswa kelas kontrol yaitu sebesar 69 dari nilai maksimum 100.

Berdasarkan analisisa perolehan skor seluruh siswa kelas kontrol pada masingmasing butir soal, perolehan skor rata-rata seluruh siswa pada soal nomor empat, nomor 
delapan, dan nomor sembilan merupakan nilai terendah dibandingkan dengan nilai rata-rata seluruh siswa pada nomor soal yang lain. Pada soal nomor empat yang mengukur kemampuan siswa dalam mengobservasi dan mempertimbangkan hasil observasi skor ratarata yang diambil dari keseluruhan siswa sebesar 1.9 dari skor maksimum 3, sedangkan soal nomor delapan yang mengukur kemampuan siswa dalam membuat induksi dan mempertimbangkan induksi rata-rata siswa memperoleh skor 1,8 dari skor maksimum 3, dan soal nomor sembilan yang mengukur kemampuan siswa dalam memutuskan suatu tindakan rata-rata siswa memperoleh skor 1,7 dari skor maksimum 3.

Sementara itu pada kelas eksperimen terdapat perbedaan rata-rata perolehan skor pada nomor empat, delapan, dan Sembilan. Pada butir soal nomor empat rata-rata siswa memperoleh skor 2,3 dari skor maksimum 3, sedangkan pada soal nomor delapan rata-rata siswa memperoleh skor 2,1 dari skor maksimum 3, dan pada soal nomor Sembilan rata-rata siswa memperoleh skor 1,6 dari skor maksimum 3.

Berdasarkan paparan di atas, terdapat perbedaan perolehan skor keterampilan berpikir kritis siswa pada butir soal nomor empat, delapan, dan Sembilan antara kelas kontrol yang tidak mendapatkan pembelajaran dengan IBL terbimbing dengan kelas eksperimen yang memperoleh pembelajaran dengan model IBL terbimbing. Perbedaan yang jelas terlihat pada butir soal nomor empat dan nomor delapan, rata-rata siswa yang diberi pembelajaran dengan menggunakan model IBL terbimbing lebih baik dalam kemampuan mengobservasi dan mempertimbangkan observasi, dan juga dalam membuat induksi dan mempertimbangkan induksi.

Di atas telah dipaparkan mengenai analisis perolehan skor rata-rata siswa pada masing-masing butir soal yang diujikan dalam mengukur keterampilan berpikir kritis siswa. Supaya lebih menggambarkan perbedaan keterampilan berpikir kritis siswa antara kelas kontrol dan kelas eksperimen, berikutnya akan dibahas mengenai perbedaan rata-rata skor keterampilan berpikir kritis siswa secara keseluruhan. Perolehan skor rata-rata keterampilan berpikir kritis siswa pada kelas kontrol sebesar 69 dari skor maksimum 100, sedangkan perolehan skor rata-rata siswa kelas eksperimen sebesar 74 dari skor maksimum 100. Berdasarkan perolehan skor rata-rata tersebut, Nampak bahwa kelas eksperimen yakni kelas yang memperoleh pembelajaran dengan model IBL terbimbing memperoleh skor rata-rata yang lebih tinggi dibandingkan dengan kelas kontrol yakni siswa yang belajar dengan model IBL terbuka.

Pengaruh pembelajaran inquiry based learning terhadap keterampilan berpikir kritis siswa dianalisis dengan menggunakan uji beda dua rata-rata dan diperoleh nilai signifikansi sebesar 0,004, nilai tersebut lebih kecil dari 0,05 sehingga terbukti bahwa terdapat perbedaan yang signifikan keterampilan berpikir kritis siswa kantara kelas eksperimen dengan kelas kontrol. Oleh karena nilai rata-rata keterampilan berpikir kritis siswa pada kelas eksperimen lebih tinggi dari kelas kontrol, sehingga dapat dikatakan bahwa keterampilan berpikir kritis siswa yang diberi pembelajaran dengan IBL terbimbing lebih baik dari siswa yang tidak menggunakan IBL terbuka, dengan demikian hipotesis ke satu terbukti.

Secara keseluruhan, deskripsi mengenai motivasi belajar pada kelas eksperimen dan kelas kontrol adalah sebagai berikut, pada kelas kontrol (yang memperoleh pembelajaran konvensional) responden dalam pengambilan data motivasi belajar siswa sebanyak 33 orang, nilai minimum yang didapat sebesar 40 dan nilai maksimum 84, nilai rata-rata motivasi belajar 
pada kelas control sebesar 65, sedangkan standar deviasi sebesar 10,9. Sementara pada kelas eksperimen (yang memperoleh pembelajaran dengan IBL terbimbing) responden dalam pengambilan data motivasi belajar sebanyak 41 orang, nilai minimum yang didapat sebesar 50 dan nilai maksimum sebesar 92, nilai rata-rata motivasi belajar pada kelas eksperimen sebesar 77,7 dan nilai standar deviasi sebesar 12, 3 .

Untuk melihat pengaruh motivasi belajar terhadap keterampilan berpikir kritis siswa, peneliti melakukan pengelompokan siswa ke dalam dua kelompok yakni kelompok siswa yang memperoleh motivasi tinggi dan siswa yang memperoleh motivasi rendah baik pada kelas eksperimen maupun pada kelas kontrol. Hasil uji statistik menunjukkan nilai signifikansi sebesar 0,000 yang mana nilai terebut lebih kecil dari 0,05 sehingga terdapat perbedaan ratarata kemampuan berpikir kritis antara siswa yang memiliki motivasi tinggi dan rendah. Karena rata-rata skor kemampuan berpikir kritis siswa yang memiliki motivasi tinggi lebih tinggi dibandingkan dengan siswa yang memiliki motivasi rendah, maka siswa yang bermotivasi tinggi memiliki kemampuan berpikir kritis yang lebih baik dibandingkan dengan siswa bermotivasi rendah.

Selain melihat pengaruh model pembelajaran inquiry-based learning terhadap keterampilan berpikir kritis siswa, dalam penelitian ini juga berusaha mengungkap pengaruh interaksi antara model inquiry-based learning dengan motivasi belajar terhadap keterampilan berpikir kritis siswa pada mata pelajaran IPA. Berdasarkan hasil uji statistik didapat nilai signifikansi sebesar 0,736 lebih tinggi dari 0,05, dengan demikian maka $H_{0}$ diterima yang artinya tidak ada interaksi antara model pembelajaran dan motivasi terhadap kemampuan berpikir kritis. Oleh karena tidak terdapat interaksi antara model inquiry based learning dengan motivasi belajar, maka dapat dipastikan bahwa skor keterampilan berpikir kritis selalu lebih tinggi yang menggunaakn model inquiry based learning untuk semua jenjang motivasi.

Hasil penelitian tersebut sejalan dengan yang dikemukakan oleh Ruli, Hala, \& Syamsiah (2018) model inquiry-based learning adalah pembelajaran yang melibatkan secara maksimal seluruh kemampuan berpikir siswa untuk mencari dan melakukan penyelidikan terhadap suatu (benda, manusia, atau fenomena) secara sistematis, kritis, logis, dan analitis sehingga mereka dapat merumuskan secara mandiri atau kelompok penemuannya dengan penuh rasa optimis.

\section{Kesimpulan}

Terdapat perbedaan yang signifikan keterampilan berpikir kritis siswa yang diberikan pembelajaran dengan inquiry based learning dan pembelajaran konvensional. Berdasarkan hal tersebut, maka pembelajaran dengan menggunakan model inquiry terbimbing berpengaruh signifikan terhadap keterampilan berpikir kritis siswa pada mata pelajaran IPA. Terdapat perbedaan yang signifikan keterampilan berpikir kritis siswa yang memiliki motivasi belajar tinggi dengan siswa yang memiliki motivasi belajar rendah, dengan demikian dikatakan bahwa motivasi belajar berpengaruh signifikan terhadap keterampilan berpikir kritis siswa pada mata pelajaran IPA. Tidak terdapat pengaruh interaksi antara model IBL terbimbing dengan motivasi belajar siswa, dengan demikian dapat dikatakan bahwa siswa yang mendapatkan pembelajaran dengan menggunakan inquiry based learning memiliki keterampilan berpikir kritis yang lebih tinggi pada berbagai kondisi motivasi belajar siswa. 
Bagi guru, model inquiry-based learning dapat dijadikan pilihan dalam melaksanakan kegiatan pembelajaran yang inovatif yang dapat menstimulus keterampilan berpikir kritis siswa sehingga diperoleh hasil belajar yang maksimal. Bagi peneliti lain, penelitian ini dibatasi pada penggunaan model inquiry-based learning yang dilakukan di kelas V SD dan melihat pengaruhnya terhadap keterampilan berpikir kritis siswa, sehingga perlu dilakukan penelitian lanjutan mengenai penggunaan model inquiry based learning pada kondisi kelas dan sekolah yang berbeda dan dikaitkan dengan kompetensi yang berbeda. Hasil penelitian ini dapat dijadikan acuan bagi peneliti lanjutan dalam melakukan penelitian dengan variabel yang sejenis dengan penelitian ini.

\section{Daftar Pustaka}

Alim, Sarwi, \& Subali, B. (2019). Implementation of Ethnoscience-based Guided Inquiry Learning on The Scientific Literacy and The Character of Elementary School Students. Journal of Primary Education, 9(2), 139-147.

Ardiyanti, \& Winarti. (2013). Pengaruh Model Pembelajaran Berbasis Fenomena Alam Untuk Meningkatkan Keterampilan Berpikir Kritis Siswa Sekolah Dasar. Jurnal Kaunia, 9 (2), $15-25$.

Ariyana. (2018). Buku Pegangan Pembelajaran Berorientasi Pada Keterampilan Berpikir Tingkat Tinggi: Program Peningkatan Kompetensi Pembelajaran Berbasis Zonasi. Jakarta: Kemendikbud RI.

Hamalik, O. (2006). Proses Belajar Mengajar. Jakarta : PT. Bumi Aksara.

Kuriawati, L.D. (2019). Penerapan Model Number Head Together untuk Meningkatkan Prestasi Belajar IPA Dipandang dari Motivasi Siswa Sekolah Dasar. Proceding disajikan pada Seminar Nasional PGSD. Yogyakarta: Program Studi PGSD Universitas Sarjanawiyata Tamansiswa.

Ngalimun. (2017). Strategi Pendidikan. Yogyakarta: Pranama Ilmu. Asmawati, E.Y.S. (2015). Lembar Kerja Siswa (LKS) Menggunakan Model Guided Inquiry untuk Meningkatkan Keterampilan Berpikir Kritis dan Penguasaan Konsep Siswa. Jurnal Pendidikan Fisika Universitas Muhammadiyah Metro, Vol. III, No. 1, 1- 16.

Nurmala, R., Ansori, Y.Z., \& Saputra, D.S. (2019). Pentingnya Model Inkuiri Terbimbing Berbasis Lingkungan dalam Pembelajaran IPA di Sekolah Dasar. Makalah disajikan pada Seminar Nasional Pendidikan. Majalengka: FKIP Universitas Majalengka

Purnomo, H., Mahpudin, \& Sunanto, L. (2020). Pengelolaan Kelas Belajar di Era 4.0. Jurnal Elementaria Edukasia, Vol. 3, No. 1, 101-108.

Putri, O.D., Nevrita., \& Hindastri, N.E.K. (2019). Pengembangan Instrumen Penilaian Keterampilan Berpikir Kritis Siswa SMA pada Materi Sistem Pencernaan. Jurnal Pendidikan Biologi Universitas Muhammadiyah Metro, Vol. 10, No. 1, 14 - 27.

Rahayu, G. (2016). Hubungan Keterampilan Berpikir Kritis dan Literasi Sains Pada Pembelajaran IPA Terpadu Dengan Model PBM dan STM. Jurnal Penelitian dan Pembelajaran IPA, Vol. 2, No. 2, 131-146.

Sanjaya, W. (2016). Strategi Pembelajaran: Berorientasi Standar Proses Pendidikan. Jakarta: Kencana Prenada Media Grup.

Suprihatin, S. (2015). Upaya Guru Dalam Meningkatkan Motivasi Belajar Siswa. Jurnal Pendidikan Ekonomi UM Metro, 73-83. 
Susilo, A. B. (2012). Pengembangan Model Pembelajaran IPA Berbasis Masalah Untuk Meningkatkan Motivasi Belajar dan Berpikir Kritis Siswa SMP. Journal of Primary Education, 57-63.

Wardani, A. R., Gummah, S., \& Ahzan, S. (2019). The Effect of Inquiry Learning Model With Pictorial Riddle Method on Students Creative Thinking Ability. Jurnal Kependidikan Fisika, 7(1), 19-23.

Wihartanti, et.al. (2019). Penggunaan Aplikasi Quizizz Berbasis Smartphone dalam Membangun Kemampuan Berpikir Kritis Mahasiswa. Proceding disajikan pada Seminar Nasional Pendidikan dan Pembelajaran. Madiun: Universitas PGRI Madiun. 